\title{
Macroeconomic Forecasts in Models with Bayesian Averaging of Classical Estimates
}

\author{
Piotr Białowolski ${ }^{1}$, Tomasz Kuszewski ${ }^{2}$, Bartosz Witkowski
}

ABSTRACT

\begin{abstract}
The aim of this paper is to construct a forecasting model oriented on predicting basic macroeconomic variables, namely: the GDP growth rate, the unemployment rate, and the consumer price inflation. In order to select the set of the best regressors, Bayesian Averaging of Classical Estimators (BACE) is employed. The models are atheoretical (i.e. they do not reflect causal relationships postulated by the macroeconomic theory) and the role of regressors is played by business and consumer tendency survey-based indicators. Additionally, survey-based indicators are included with a lag that enables to forecast the variables of interest (GDP, unemployment, and inflation) for the four forthcoming quarters without the need to make any additional assumptions concerning the values of predictor variables in the forecast period. Bayesian Averaging of Classical Estimators is a method allowing for full and controlled overview of all econometric models which can be obtained out of a particular set of regressors. In this paper authors describe the method of generating a family of econometric models and the procedure for selection of a final forecasting model. Verification of the procedure is performed by means of out-of-sample forecasts of main economic variables for the quarters of 2011. The accuracy of the forecasts implies that there is still a need to search for new solutions in the atheoretical modelling.
\end{abstract}

KEY WORDS: Bayesian Averaging of Classical Estimates, business survey data, seasonality, automatic forecasting

JEL Classification: C10, C83, E32, E37

${ }^{1}$ Warsaw School of Economics, POLAND

${ }^{2}$ Univesrity of Finance and Management in Warsaw, POLAND

\section{Introduction}

The main aim of this paper is to construct a model that would accurately forecast basic macroeconomic indicators, i.e. the GDP growth rate (GDP), the consumer price inflation (CPI), and the unemployment rate (UNE) measured in line with the methodology of the Polish Labour Force Survey (BAEL). The model presented in this paper is by definition atheoretical, i.e. its specification does not intend to reflect the causal relations driven from the economic theory. Additionally, it is based on the results of business and consumer tendency surveys.

Corespondence concerning to this article should be addressed to: bwitko@sgh.waw.pl
The events of the crisis period proved that Diebold's concern about macroeconomic forecasting was justified. Dynamic simultaneous equations models, general equilibrium models, dynamic stochastic general equilibrium models and vector autoregressive (VAR) models were predominantly unable to generate accurate short-term macroeconomic predictions in that period.

The concept of an atheoretical model construction was proposed by Sargent and Sims (1977) and Sims (1980). The idea was either acknowledged or criticised for being "atheoretical macroeconomics" (Cooley \& LeRoy, 1985). Nevertheless, later it was distinguished by the Nobel Memorial Prize in Economic Sciences.

One of the first scholars to employ atheoretical modelling augmented with business and consumer survey 

where $L\left(D, \hat{\theta}_{i}\right)$ is the likelihood function of model $M_{i}$, and $\hat{\theta}_{i}$ is the $k_{i}$-element vector of parameters of $M_{i}$ (standing by each $X_{i}$ ). Although finding the value of formula (3) is complicated in terms of calculation, it does not constitute a barrier to the utilisation of this method since (3) can be approximated with the Bayesian Schwarz's information criterion:

$$
P\left(D \mid M_{i}\right)=\exp \left(\ln L\left(D, \hat{\theta}_{i}\right)-0,5 k_{i} \ln n\right),
$$

where $L\left(D, \hat{\theta}_{i}\right)$ is the value of the likelihood function of model $M_{i}$ with a vector of parameter estimates $\hat{\theta}_{i}$. In estimation procedure of a model with least squares, the value of $L\left(D, \hat{\theta}_{i}\right)$ may be replaced with $-0,5 T \ln S S E_{i}$, where $S S E_{i}$ stands for the residual sum of squares of $M_{i}$. This changes formula (2) into the following:

$$
P\left(M_{i} \mid D\right)=\frac{P\left(M_{i}\right) n^{-k_{i} / 2} S S E_{i}^{-n / 2}}{\sum_{j=1}^{2^{s}} P\left(M_{j}\right) n^{-k_{i} / 2} S S E_{j}^{-n / 2}}
$$

Formula (5) is of key importance as it defines the degree to which data suggest the "correctness" or "relevance" of model $M_{i}$. It can be used to estimate the expected value and the variation of parameters of regression $\beta_{i}$ for the particular variables $X_{i}$ in a linear model including a dependent variable $Y$ as:

$$
E\left(\beta_{i} \mid D\right)=\sum_{j=1}^{2^{s}} P\left(M_{j} \mid D\right) \hat{\beta}_{i, j}
$$

and

$$
\begin{aligned}
& D^{2}\left(\beta_{i} \mid D\right)=\sum_{j=1}^{2^{s}} P\left(M_{j} \mid D\right) \cdot D^{2}\left(\beta_{i, j} \mid D, M_{j}\right)+ \\
& +\sum_{j=1}^{2^{s}} P\left(M_{j} \mid D\right) \cdot\left(\hat{\beta}_{i, j}-E\left(\beta_{i} \mid D\right)\right)^{2},
\end{aligned}
$$

where the value of $\hat{\beta}_{i, j}$ is an estimate of the parameter of regression $\beta_{i}$ (for a given variable $X_{i}$ ), which has been calculated with ordinary least squares in model $M_{j}$. Moreover, since formula (5) may be employed for the purposes of establishing the level of "correctness" of a given model, the posterior probability that variable $X_{i}$ can be included in the "correct" model may be expressed by:

$$
P\left(\beta_{i} \neq 0 \mid D\right)=\sum_{j=1}^{2^{s}} P\left(M_{j} \mid D\right) \cdot I_{\beta_{i, j} \neq 0},
$$

where $I_{\beta_{i, j} \neq 0}$ is an indicator of the presence of variable $X_{i}$ in $M_{j}$ and it takes on value 1 if the variable $X_{i}$ is included in the model $M_{j}$ and 0 otherwise.

It is noteworthy that assuming independence and exogeneity of particular regressors, the only parameter which requires a prior assumption is $\bar{s}$. As a rule, $\bar{s}$ is given a value that reflects the expected number of predictor variables in the "correct" model. However, it is difficult to talk about the "correct" model since the following considerations are of atheoretical nature.

Application of the BACE algorithm is time consuming as it requires a considerable number of models (precisely $2^{s}$ ) to be estimated. In the estimations carried out by Sala-i-Martin, Doppelhofer, and Miller (2004), the number of variables amounted to 60, which made estimation of all possible models unattainable. The common practice in such situations is to estimate only a part of all possible equations on the basis of sets of regressors randomly selected from the initial set.

In order to employ the BACE algorithm, a set of potential regressors and the regressant must be predefined. Furthermore, the regressors selected for the final model are not actually orthogonal which may result in the problem of collinearity. Consequently, if we treat BACE as an algorithm of pre-selection of variables for the final model only, which is the most frequent type of approach, it is necessary to verify the possible excessive collinearity of some regressors andprobably - to modify also the list of selected variables. Consequently, sequence of activities presented below was followed:

1. It was assumed that the aim of this paper is to construct models of the following form:

$$
\begin{aligned}
& G D P_{t}=\beta_{0}^{1}+\gamma^{1} G D P_{t-1}+\mathbf{x}_{t-m}^{1}{ }^{\prime} \boldsymbol{\beta}^{1}+\varepsilon_{t}^{1} \\
& U N E_{t}=\beta_{0}^{2}+\gamma^{2} U N E_{t-1}+\mathbf{x}_{t-m}^{2} \cdot \boldsymbol{\beta}^{2}+\varepsilon_{t}^{2} \\
& C P I_{t}=\beta_{0}^{3}+\gamma^{3} C P I_{t-1}+\mathbf{x}_{t-m}^{3} \boldsymbol{\beta}^{3}+\varepsilon_{t}^{3}, \quad 1=1, \ldots T ; m \in\{1 ; 3\}
\end{aligned}
$$

where:

$G D P, G D P_{t-1}$ - is the current and one-quarter lagged GDP growth rate expressed in the year-on-year basis.; $U N E_{t}, U N E_{t-1}$ - is the current and one-quarter lagged indicator of the unemployment rate according to the Polish Labour Force Survey;

$C P I_{t}, C P I_{t-1}$ - is the current and one-quarter lagged indicator of the consumer price inflation;

$\mathbf{x}_{t-m}^{1, m}, \mathbf{x}_{t-m}^{2, m}, \mathbf{x}_{t-m}^{3, m}$ - are vectors of regressors selected from indices of economic tendency surveys lagged by 

tions identified in previous research of the authors (Białowolski, Kuszewski \& Witkowski 2010).

The dependent variables in models comprise simple balances regarding an answer to a single question in a questionnaire, composite indicators combining information acquired by means of several questions, and the information inferred from national statistics. Nine composite indicators and nine balances were used in the analysis of the Polish economy. Additionally, four composite indicators concerning the state and the forecasts of the German economy were employed.

The group of composite indicators for the Polish economy comprises five indicators developed at the Research Institute for Economic Development at the Warsaw School of Economics (WSE). These indicators concern the economic situation of manufacturing (ind_r), the economic situation of households (hhs), the economic situation of the construction industry (constr), the economic situation in trade (trade) and the economic situation in agriculture (agri) - information on the economic situation in the particular sectors of economy and the methodological basis for the construction of the indicators in these sectors is available in research papers of the Research Institute for Economic Development (RIED) at WSE respectively: Adamowicz \& Walczyk, 2011; Majchrzak, 2010; Gorzelak \& Zimny 2010; Białowolski \& Dudek, 2010; Podgórska, 2010. The indicators contain information about the major part of economic activity performed in Poland, which is potentially important in the analysis conducted with the BACE method as a wide variety of indicators can be selected in the preliminary set.

The additional group of indicators encompasses data acquired from the BIEC which is a company oriented on providing composite indicators for the Polish economy. The following indicators were employed in the current study: the leading indicator for the economic situation (wwk), the future inflation index (wpi), and the labour market index (wrk). The proper methodological basis can be found in the literature (inter alia: Białowolski et al., 2007; Białowolski \& Żochowski, 2006; Pater, 2006).

The initial set of predictors also contains a variable not derived directly from data on the economic situation but reflecting the economic situation observed by logistics managers - the PMI ${ }^{\mathrm{TM}}$ published by the HSBC bank. The index is based on individual diffusion indices which reflect changes in production, new orders, time of delivery, and inventory of purchased goods. It is commonly recognised that the economic situation in the logistics sector is a leading indicator in the business cycle. This claim is substantiated in the book by Zarnovitz (1992) who points to an apparent tendency of new orders for suppliers to significantly lead other variables in the business cycle.

The models also utilise four series reflecting the performance of the German economy which is currently the biggest trade partner of Polish companies. The demand for Polish export depends to a large extent on the economic situation abroad. The series published by the Institute IFO in Munich (ifo_bs - an indicator reflecting the current business situation, ifo_be - an indicator reflecting the expectations of entrepreneurs, and ifo_bc - reflecting the general business climate in Germany) were used as well as the indicator constructed by ZEW (zew_ies - an Indicator of Economic Sentiment) which was employed in the study for the purposes of describing the situation in Germany. This indicator is derived from the opinions of professionals from Germany concerning the economic development in this country in consecutive six months.

In addition to synthetic indicators, the preliminary set of variables also comprised the time series selected from the survey conducted in the manufacturing industry and the State of the Households Survey. Due to the authors' objectives (i.e. creation of forecasts) only the indicators concerning expectations were taken into account in the analysis. As far as the survey on the economic situation in the manufacturing industry is concerned, the indicators relating to the forecast of orders (q2f) and the forecast of inventory (q4f) were selected. While the indicator concerning orders has a clear tendency to lead, the indicator concerning inventory has a tendency to be lagged rather than to lead in the cycle (Zarnovitz, 1992). Nevertheless, the indicators concerning inventory are very reliable and are recommended by the European Commission for creating a synthetic index of the economic situation in the manufacturing industry (European Commission, 2006). Furthermore, since this study is also devoted to forecasting inflation and unemployment, the forecasting series of price changes (q5f) and the expected employment in companies (q6f) are also taken into account as far as the survey on the economic situation in industry is concerned. 
The study made use of the following questions asked in the State of the Households Survey: predictions of the general economic situation (hhs_q4), unemployment changes forecasts (hhs_q7), inflation expectations (hhs_q5), and forecasts of durable goods purchases (hhs_q9). The first three are directly related to the areas of interest in this forecast (the GDP, unemployment, and inflation). As the matter of fact, purchases of durable goods are very sensitive towards the expected variation in the economic situation. This factor is also the most volatile element of households' consumption and, therefore, the forecast of the behaviour of households in this respect constitutes an important factor influencing the forecasts of the general economic situation.

Databases contain time series of quarterly data from business and consumer tendency surveys in Poland conducted between the first quarter of 1996 and the first quarter of 2011, and time series of regressants for the period between the first quarter of 1996 and the fourth quarter of 2010.

\section{Estimation of the econometric models}

In order to employ the algorithm of BACE in the study, it is necessary to assume $\bar{s}$ - a number of predictor variables in the "correct" model. The value of this number is assumed arbitrary, which is especially typi$\mathrm{cal}$ of atheoretical models. Basing on the previous re- search results by Białowolski, Kuszewski \& Witkowski (2010), it has been assumed that $\bar{s}=6$, however, it is noteworthy that the final number of predictor variables in particular models may differ from the prior assumption. Simultaneously, the influence of a change in the value of $\bar{s}$ on the set of predictor variables has been tested. The research leads to the conclusion that assuming that $\bar{s}=6$ is adequate. Bigger models often require the excessive number of variables to be eliminated due to their collinearity. Furthermore, the values of probabilities calculated in line with (8) change proportionally to $\bar{s}$ but the order of values (8) for each indicator of the economic situation is preserved.

The initial set of indicators of the economic situation, which are under discussion, comprises 22 variables. If we assume that $\bar{s}=6$, theoretically variables whose probability ( 8 ) is over $6 / 22 \approx 0.27$ should be included in the set. Table 1 contains the expected values of parameters (6), the Bayesian probabilities of inclusion (8) and the weighted empirical significance levels for test $t$. This paper presents only the results of estimation of models employing the three-period $(m=3)$ lagged indices of an economic situation. The results of estimation of models using one-period lagged indices of an economic situation $(m=1)$ were not discussed in the text due to the fact that the forecast acquired through the use of these models occurred highly unsatisfactory ${ }^{1}$.

Table 1. The results of the predictors selection process with application of the BACE algorithm in models with three-period lagged business and consumer sentiment indicators $(m=3)$

\begin{tabular}{lccccccccc}
\hline Regressant $\rightarrow$ & \multicolumn{3}{c}{ GDP } & & & UNE & & \multicolumn{3}{c}{ CPI } \\
\hline predictor variables & $E(\beta)$ & $P(X)$ & $t(X)$ & $E(\beta)$ & $P(X)$ & $t(X)$ & $E(\beta)$ & $P(X)$ & $t(X)$ \\
\hline ifo_bc & -0.040 & 0.115 & 0.185 & -0.017 & 0.075 & 0.438 & -0.012 & 0.100 & 0.321 \\
ifo_bs & -0.029 & 0.043 & 0.217 & -0.009 & 0.084 & 0.445 & -0.038 & 0.084 & 0.273 \\
ifo_be & -0.052 & 0.208 & 0.065 & -0.012 & 0.059 & 0.507 & 0.047 & 0.128 & 0.207 \\
zew_ies & -0.003 & 0.027 & 0.286 & -0.003 & 0.111 & 0.412 & -0.001 & 0.064 & 0.511 \\
Pmi & -0.001 & 0.040 & 0.193 & -0.001 & 0.111 & 0.210 & -0.002 & 0.656 & 0.015 \\
biec_wwk & -0.002 & 0.043 & 0.679 & -0.049 & 0.505 & 0.049 & -0.009 & 0.080 & 0.296 \\
biec_wpi & -0.025 & 0.027 & 0.405 & 0.118 & 0.626 & 0.009 & -0.077 & 0.176 & 0.186 \\
biec_wrp & -0.021 & 0.037 & 0.343 & 0.038 & 0.109 & 0.256 & 0.020 & 0.105 & 0.336 \\
ind_q1f & -0.020 & 0.101 & 0.120 & 0,025 & 0.151 & 0.132 & 0.016 & 0.119 & 0.264 \\
ind_q2f & 0.001 & 0.022 & 0.470 & -0001 & 0.061 & 0.508 & -0.003 & 0.359 & 0.143
\end{tabular}


Table 1. (continued)

\begin{tabular}{l|ccc|ccc|ccc}
\hline Regressant $\rightarrow$ & \multicolumn{3}{|c}{ GDP } & \multicolumn{3}{c|}{ UNE } & \multicolumn{3}{c}{ CPI } \\
\hline predictor variables & $E(\beta)$ & $P(X)$ & $t(X)$ & $E(\beta)$ & $P(X)$ & $t(X)$ & $E(\beta)$ & $P(X)$ & $t(X)$ \\
\hline ind_q4f & 0.040 & 0.033 & 0.342 & 0.078 & 0.177 & 0.088 & -0.100 & 0.331 & 0.060 \\
ind_q5f & -0.019 & 0.146 & 0.172 & -0.008 & 0.196 & 0.549 & -0.008 & 0.093 & 0.541 \\
ind_q6f & 0.006 & 0.022 & 0.490 & 0.0128 & 0.100 & 0.363 & 0.001 & 0.058 & 0.456 \\
ind_r & 0.001 & 0.018 & -0.013 & 0.001 & 0.112 & 0.567 & 0.004 & 0.803 & 0.009 \\
hhs_q4 & 0.009 & 0.032 & 0.417 & -0013 & 0.129 & 0320 & 0.018 & 0.151 & 0.216 \\
hhs_q6 & -0.043 & 0.992 & 0.001 & -0.011 & 0.174 & 0.281 & -0.006 & 0.091 & 0.509 \\
hhs_q7 & -0.006 & 0.084 & 0.435 & 0004 & 0.079 & 0.475 & -0.021 & 0.282 & 0.098 \\
hhs_q9 & 0.003 & 0.020 & 0.591 & -0.033 & 0.772 & 0.009 & 0.038 & 0.726 & 0.010 \\
Hhs & 0.009 & 0.028 & 0.401 & -0.028 & 0.193 & 0.276 & 0.009 & 0.152 & 0.222 \\
Trade & -0.018 & 0.027 & 0.271 & 0.043 & 0.848 & 0.003 & -0.009 & 0.074 & 0.564 \\
Agri & -0.014 & 0.032 & 0.344 & -0.054 & 0.916 & 0.002 & -0.061 & 0.539 & 0.017 \\
Constr & -0.003 & 0.051 & 0.595 & -0.012 & 0.086 & 0.251 & 0.016 & 0.253 & 0.145 \\
Y(t-1) & 0.858 & - & 0.000 & 0.841 & - & 0.000 & 0.844 & - & 0.000 \\
\hline
\end{tabular}

Note: $Y(t-1)$ denotes a one-quarter lagged variable, i.e. GDP, UNE or CPI respectively; denotes parameters estimated along with the formula (6), $P(X)$ those estimated along with formula (8), $t(X)$ is an average of the empirical significance level of a given variable with weighs estimated in line with formula (5).

The BACE algorithm assumes independence of regressors. In fact, it would be hard to find an area in macroeconomics where a relationship between variables considered as regressors were inexistent. Therefore, the set of regressors finally included in models under consideration was slightly modified by means of excluding the variables responsible for an increase in collinearity from the set. Additionally, in one case, the set of variables was expanded by one variable whose Bayesian probability of inclusion was slightly below 0.27 . If strict rules governing the algorithm of BACE had been maintained in this case, the equation under consideration would contain one regressor only.

Table 1 contains also the average empirical significance levels for test $t$. They have been estimated as weighted averages of the empirical significance levels for the particular variables in each model where weighs are calculated in line with formula (5). It is noteworthy that an almost identical set of regressors $\mathbf{x}_{t-m}^{1, m}, \mathbf{x}_{t-m}^{2, m}, \mathbf{x}_{t-m}^{3, m}$ would be selected if the average empirical significance levels for test $t$ were taken into account (as with the use of the Bayesian probabilities of inclusion).
After having selected the variables with the use of the BACE and having eliminated the variables causing statistical collinearity, the final forms of models were estimated and applied for the purposes of forecasting afterwards. Table 2 contains the results of estimation of models.

The Final forms of models underwent standard statistical verification. The models occured to be welladjusted to empirical data. The series of residuals of models were found to be stationary, the normality of residuals in all models could not be rejected, no phenomenon of heteroscedasticity of residuals was observed, and the statistical significance of the set of predictor variables was confirmed.

Although as a rule there is no need for substantive interpretation of the carried out estimations and sets of predictor variables selected with the use of the method of BACE, several facts are noteworthy. In line with the initial intention, all equations contain predictor variables which are one-period lagged dependent variables. The equation concerning changes in the gross domestic product takes into account the influence of the external environment on the GDP (ifo_be) 
and the expectations of households with respect to prices (hhs_q6). The equation concerning the unemployment rate unexpectedly takes into account the balance of answers referring to the purchase of durable goods acquired through the survey on the economic situation of households (hhs_q9), the leading indices of the economic situation and inflation (biec_wwk and biec_wpi), and the results of a test on the economic situation in agriculture and trade. The equation concern- ing changes in the consumer price inflation takes into account, among the regressants, the balance of answers to questions asked in the households' survey regarding the unemployment forecast (hhs_q7), purchases of durable goods (hhs_q9), and expectations concerning the inventory of manufacturing companies (ind_qf4). However, no variables regarding the perception of the processes on the market of consumption goods are included.

Table 2. Results of econometric models with three-period lagged business and consumer survey indicators $(m=3)$

\begin{tabular}{|c|c|c|c|c|c|c|}
\hline \multirow[t]{2}{*}{ Regressant $\rightarrow$} & \multicolumn{2}{|c|}{ GDP } & \multicolumn{2}{|c|}{ UNE } & \multicolumn{2}{|c|}{ CPI } \\
\hline & GDP $(t-1)$ & 16.20 & UNE(t-1) & 18.47 & CPI(t-1) & 17.82 \\
\hline & ifo_be & -2.59 & biec_wwk & -1.80 & pmi & -2.16 \\
\hline \multirow{6}{*}{$\begin{array}{l}\text { Predictor variables and values } \\
\text { of t Student statistics }\end{array}$} & hhs_q6 & -4.68 & biec_wpi & 2.98 & ind_q4f & -2.59 \\
\hline & & & hhs_q9 & -3.97 & ind_r & 4.64 \\
\hline & & & trade & 3.64 & hhs_q7 & -2.06 \\
\hline & & & agri & -7.01 & hhs_q9 & 2.06 \\
\hline & & & & & agri & -4.13 \\
\hline & & & & & constr & 1.73 \\
\hline Adj. R-squared & 0.8612 & 0.9790 & 0.9776 & & & \\
\hline
\end{tabular}

Table 3. Out-of-sample forecasts of GDP, CPI and UNE for the quarters of 2011 based on econometric models with three-period lagged business and consumer survey indicators $(m=3)$

\begin{tabular}{|cc|cc}
\hline Quarters & GDP & UNE & CPI \\
\hline I & 4.5 & 9.5 & 3.4 \\
II & 3.8 & 8.7 & 3.4 \\
III & 2.5 & 7.9 & 3.0 \\
IV & 1.2 & 8.1 & 2.9 \\
\hline
\end{tabular}

\section{Forecasts and conclusions}

The lags of predictor variables in the econometric models were selected in such a way so as to enable the forecast of GDP, UNE, and CPI four quarters ahead without the need to make additional assumptions concerning the values of predictor variables in the forecast period. As already mentioned, the last observation in the time series of regressants was reported for the fourth quarter of 2010 and the last observation in the time series of data acquired from the economic tendency surveys was reported for the first quarter of 2011.
Since regresants lagged by one period are included as predictor variables, it is necessary to perform the forecast for four successive quarters in a stepwise manner. The values of regressors - variables derived from the tendency surveys performed in the past - are known for the whole period of forecast. The predicted values of the GDP, UNE, and CPI for a given quarter will become the values of predictor variables in the consecutive quarter. Such a procedure is faulty since it leads to accumulation of forecast errors. Table 3 presents the results of the forecasting process for the four quarters of 2011. 
The values acquired in the forecasts point to the necessity of consideration of further improvement of forecasting models. According to the Central Statistical Office, the variable GDP took the value of 4.4 and 4.3 in the first two quarters of 2011, the variable UNE took the values of 10.0 and 9.5 in the same period, and the variable CPI took the values 3.8 and 4.6 in these periods. The forecasts draw attention to a rapid decrease in the rate of growth of the gross domestic product, which was not in line with the expectations of analysts. On the contrary, the estimates of the state of the labour market and the consumer price inflation seem to be too optimistic.

Further research in the field of forecasting models of basic macroeconomic variables employing survey data will encompass the inclusion of dynamic factor models into the set of models under analysis (Boivin \& $\mathrm{Ng}$, 2005; Forni \& Reichlin, 1998; Stock \& Watson, 2002). Furthermore, the possibilities raised by the forecasting models whose parameters are estimated on the basis of time series with removed seasonal effects should be considered further, especially the methods of deseasonalization taking different phases of the economic situation into account (Canova \& Ghysels, 1994).

\section{References}

Anuszewska I. (2010). Sondaże - zwierciadło społeczeństwa. Rytuały komunikacyjne a kreowanie wiedzy wspólnej [Surveys - the Reflection of Society. Communication Rituals and Formation of Common Knowledge]. Warszawa: Wydawnictwo Fachowe CeDeWu.pl.

Adamowicz, E., \& Walczyk, K. (2011). Koniunktura w przemyśle - Polska, styczeń 2011 [The Economic Situation in Manufacturing Industry- Poland, January 2011]. Warszawa: Instytut Rozwoju Gospodarczego SGH.

Białowolski P., Drozdowicz-Bieć M. (Ed.), Lada K., Pater, R., Zwiernik P., Żochowski D., (2007). Forecasting with composite coincident and leading indexes and the CLIMA model. Warsaw: Warsaw School of Economics.

Białowolski, P., Kuszewski, T., Witkowski, B. (2010). Prognozy kombinowane wskaźników makroekonomicznych $\mathrm{z}$ użyciem danych $\mathrm{z}$ testów koniunktury [Combined Forecasts of Macroeconomic Indicators with Business Survey Data]. Współczesna Ekonomia, 4(16), 41-58.
Białowolski, P., Kuszewski, T., Witkowski, B., (2011). Prognozy podstawowych wskaźników makroekonomicznych z użyciem danych $z$ testów koniunktury [Forecast of Basic Macroeconomic Indicators with the Use of Business Survey Data], IV Konferencja Naukowa Modelowanie i Prognozowanie Gospodarki Narodowej. Uniwersytet Gdański, Wydział Zarządzania, Gdańsk.

Białowolski, P., \& Dudek, S. (2010). Kondycja gospodarstw domowych - badanie okresowe II kwartat 2010 [The State of the Households Periodic Survey: 2nd Quarter of 2010]. Warszawa: Instytut Rozwoju Gospodarczego SGH.

Białowolski, P., \& Żochowski, D. (2006), Analiza własności prognostycznych komponentów WPI. W: Wskaźniki wyprzedzajace [The Analysis of Forecast Properties of the Future Inflation Index. In: Leading Indicators]. Prace i Materiały Instytutu Rozwoju Gospodarczego SGH. Warszawa: Instytut Rozwoju Gospodarczego SGH.

Bieć M. (1996). Test koniunktury - metody, techniki, doświadczenia [Economic Tendency Surveys - Methods, Techniques, Experiments]. Prace i Materiały Instytutu Rozwoju Gospodarczego, zeszyt 48. Warszawa: Instytut Rozwoju Gospodarczego SGH.

Boivin, S. \& Ng, S. (2005). Understanding and comparing, factor-based forecasts. International Journal of Central Banking. December, 117-151.

Canova F., \& Ghysels E. (1994). Changes in seasonal patterns. Are they cyclical? Journal of Economic Dynamics \& Control, 18, 1143-1171.

Cooley, T.F. \& LeRoy, S.F. (1985). Atheoretical macroeconomics: a critique. Journal of Monetary Economics, 16(3), 283-308.

Diebold F.X. (1998). The past, present and future of macroeconomic forecasting. The Journal of Economic Perspectives, 12(2), 175-192.

European Commission (2006). The joint harmonised EU programme of business and consumer surveys. European economy - Report and studies No 5. Bruksela: Belgia.

Forni, M. \& Reichlin, L. (1998). Let's get real: a factor analytical approach to disaggregateg business cycle dynamics. The Review of Economic Studies, $65,453-473$. 
Gorzelak, E., \& Zimny, Z. (2010), Koniunktura w rolnictwie. Badanie okresowe - II kwartał 2010 [The Economic Situation of Agriculture. Periodic Study for the 2nd Quarter of 2010]. Warszawa: Instytut Rozwoju Gospodarczego SGH.

Hansson J., Jansson, M., \& Lof M. (2003). Business survey data: do they help in forecasting the macro economy? Working Paper 84. Stockholm: The National Institute of Economic Research,

Majchrzak, K. (2010). Koniunktura w handlu. Badanie okresowe - II kwartat 2010 [The Economic Situation of Trade. Periodic Study for the 2nd Quarter of 2010]. Warszawa: Instytut Rozwoju Gospodarczego SGH.

OECD (2003). Business tendency surveys - a handbook. Paris: OECD.

Pater, R. (2006). Analiza przebiegu i wskazań wskaźnika rynkupracy. W: Wskaźnikiwyprzedzające [The Analysis of Labour Market Index. In: Leading Indicators], Prace i Materiały Instytutu Rozwoju Gospodarczego SGH. Warszawa: Instytut Rozwoju Gospodarczego SGH.

Podgórska, M. (2010). Koniunktura $w$ budownictwie. Badanie okresowe - II kwartat 2010 [The Economic Situation of Construction Industry. Periodic Study for the 2nd Quarter of 2010]. Warszawa: Instytut Rozwoju Gospodarczego SGH.

Sala-i-Martin X., Doppelhofer G., Miller R. (2004). Determinants of long-term growth: a bayesian averaging of classical estimates (BACE) approach. American Economic Review, 94, 813-835.

Sargent, T., \& Sims, C.A. (1977). Business cycle modeling without pretending to have too much a-priori economic theory. In: C. Sims (Ed.), New methods in business cycle research. Minneapolis, MN: Federal Reserve Bank of Minneapolis.

Sims, C.A. (1980). Macroeconomics and reality. Econometrica, 48, 1-48.

Stadelmann D. (2010). Which factors capitalize into house prices? A bayesian averaging approach. Journal of Housing Economics, 19(3), 180-204.

Stock, J. \& Watson, M. (2002). Forecasting using principal components from a large number of predictors. Journal of the American Statistical Association, 97, 1167-1179.

Zarnovitz, V. (1992), Business cycles: theory, history, indicators and forecasting. Chicago, IL: National Bureau of Economic Research.

\section{Notes}

1 It is probable that the superiority of models with $m=3$ is a consequence of a certain seasonal quality of the series under analysis. 